\title{
KRITIK IMMANUEL KANT TERHADAP \\ FAHAM RASIONALISME DAN EMPIRISME
}

\author{
JAUHAN BUDIWAN ${ }^{1}$
}

\begin{abstract}
Immanuel Kant is one of the most influential philosophers in the history of Western philosophy. His contributions to metaphysics, epistemology, ethics, and aesthetics have had a profound impact on almost every philosophical movement that followed him. This portion will focus on his metaphysics and epistemology in one of his most important works. The Critique of Pure Reason, A large part of Kant's work addresses the question "What can we know?" The answer, if it can be stated simply, is that our knowledge is constrained to mathematics and the science of the -natural, empirical world. It is impossible, Kant argues, to extend knowledge to the supersensible realm of speculative metaphysics.

The reason that knowledge has these constraints, Kant argues, is that the mind plays an active role in constituting the features of experience and limiting the mind's access to the empirical realm of space and time. In order to understand Kant's position, we must understand the philosophical background that he was reacting to. First, 1 will present a brief overview of his predecessor's positions with a brief statement of Kant's objections, then I will return to a more detailed exposition of Kant's arguments. There are two major historical movements in the early modem period of philosophy that had a significant impact on Kant; Empiricism and Rationalism,
\end{abstract}

\section{Keynote words:}

Kant, metaphysics, epistemology, ethics, aesthetics, empiricism,rationalism.

\section{Pendahuluan}

Perkembangan alam pikiran Barat hingga awal abad ke delapan belas telah menempatkan filsafat sebagai pengetahuan yang mempunyai pamor tinggi. Tidak dapat disangkal, filsafat merupakan induk segala ilmu, the queen of the sciences, karena dari padanya berkembang ilmu-ilmu pengetahuan yang beragam sampai pada spesifikasi khusus. Dewasa ini muncul Ilmu-ilmu semacam mikrobiologi, genetika, perbintangan, teknik nuklir dsb, yang keberadaannya tidak mungkin di

\footnotetext{
${ }^{1}$ Penulis adalah dosen Institut Agama Islam Sunan Giri Ponorogo
} 
pahami selain dalam kaitannya dengan filsafat.

Disamping itu filsafat telah menyumbangkan pemikiran besar dan mampu menggerakkan orang untuk merubah masyarakat. Socrates ( $\pm 470-399$ SM), Plato ( \pm 427-347 SM) dan Aristoteles $( \pm 384-322 \mathrm{SM})$, tiga orang tokoh filosof Yunani yang hidup antara 500-300 sebelum Masehi adalah filosof-filosof peletak dasardasar pemikiran dan menjadi benih-benih gagasan besar dalam perubahan masyarakat. Seperti idealisme, demokrasi, kritisisme, konstitusi, keadilan sosial, hak asasi manusia yang dikembangkan oleh para filosof berikutnya. Dalam hal ini filsafat mempunyai arti sebagai pemikiran dasar yang melahirkan doktrin-doktrin besar kenegaraan, moralitas, sosial, dan keagamaan hingga menjadi bahan perbincangan banyak orang. ${ }^{2}$ Dilihat demikian, filsafat dapat dikatakan memberi dasaran pemikiran imtuk pegangan hidup, Weltanschauung yaitu berupa wawasan luas dan proyeksi masa depan. Namun pengertian filsafat yang demikian mulai dikritik, diantaranya oleh para ilmuwan dan oleh filosof sendiri. Kritikan ini dapat diartikan tidak puas dengan peran filsafat yang jauh dari jangkauan praktis masyarakat. $^{3}$

Dari latar belakang seperti ini muncul persoalan-persoalan konkrit dan sederhana, berupa hal-hal praktis dalam kehidupan. Hal ini disebabkan karena adanya kebiasaan yang diikuti masyarakat secara konversional tanpa mempersoalkan 'sesuatunya' lebih lanjut. Dengan demikian filsafat dapat

\footnotetext{
${ }^{2}$ Mengenai definisi filsafat, banyak ahli melihat dengan berbagai sudut padang yang berbeda hingga definisinya singat. beragam. Namun secara garis besar bahwa filsafat adalah tuntutan untuk mengetahui dan memahami dengan pola pikir masing-masing. Lihat David Trueblood, Filsafat Agama (terj.) IIM. Rasyidi (Jakarta: Bulan Bintang cet. IX, 1994), 3

${ }^{3}$ M. AniiB Abdullah, Antara al - Ghozali dan Kunt: Filsafat Etika Islam (terj.) Huzah, Husein Heriyanta (Bandung; Mizan, 2002), 46.
} 
memanfaatkan kesempatan untuk memusatkan perhatian pada persoalan-persoalan batas, kemungkinan-kemungkinan yang ada di balik kehidupan yang biasa.

\section{Zaman Baru, Ide Baru}

Memasuki abad 18 Masehi muncul perkembangan baru dalam dunia filsafat. Lahirnya era Aufklarung di Jerman, Enlightenment di Inggris atau dapat diistilahkan sebagai zaman pencerahan. Dinamakan demikian karena era Aufklarung disebut juga sebagai zaman rasio sebagai proses emansipasi manusia Barat, yang sebenamya sudah dimulai dari sejak Renaisance dan Reformasi.

Salah satu tokoh yang berperan setelah pergerakan ini adalah Immanuel Kant, dan bahkan Kant dapat dikatakan telah melebihi era Aufklarung. ${ }^{4}$ Immanuel Kant lahir di kola Konigserg, Prusia Timur sebuah wilayah di Jerman, namun sekarang telah meniadi safari satu wilayah bekas Uni Sovyet bernama Kaliningrad pada tahun 1724. Dia berkembang dalam suasana kekristenan yang saleh, menyelesaikan pendidikan menengah di kotanya sebelum ia masuk di Universitas Konigsberg dan sempat mengajar di universitas ini, hingga mendapatkan gelar profesor logika dan metafisika tahun 1770. Pada 1796 dia berhenti memberi kuliah dengan alasan kesehatan hingga 1804 ia meninggal dalam keadaan pikun. ${ }^{5}$

Kant hidup pada zaman scepticism dan banyak membaca karya-karya Voltaire dan Hume hingga ada 'pemberontakan' dalam dirinya. Yang akhirnya jadi semacam pertanyaan mendasar; what can we do? what is nature? dan what are

\footnotetext{
${ }^{4}$ Immanuel Kant bahkan dijuluki oleh D.W. Hamlyn sebagai the great giant of eighteenth century philosophy, hal ini dapat disesuaikan dengan berbagai peran dan pola pikirnya yang memamng besar dan berpengaruh hingga saat ini. D.W. Hamlyn, The Penguin History of Western Philosophy (London: The Penguin Group, 1987), 217.

5 Diane Collisin, Lima Puluh Filosof Dunia yang Menggerakkan (terj) Ma'mur Ilzamuddin dkk, (Jakarta: Rajawali Grafindo Persada, 2001), 131.
} 
the limits of human knowledge? Dari ketiga pertanyaan dasar inilah awal mula filosofi Kant dikenal orang, Apalagi setelah beberapa karyanya dibaca masyarakat luas. Tulisannya sampai sekarang masih concern dengan ilmu-ilmu alam dan menggambarkan benih pemikirannya di kemudian hari. Semisal The Critique of Pure Reason disusul kemudian oleh Prolegonema to Any future Metaphysic (1783), the Groundwork of the Metaphysic of Morals (1785), the Critique of Practical reason (1788), Metaphysical foundations of natural science. Religion within the limits of reason alone (1793). ${ }^{6}$

Sebagai seorang fiiosof, perkembangan pemikiran Kant dapat dibagi dalam empat periode $;^{7}$ periode pertama ketika ia masih dipengaruhi oleh LeibnizWolff sampai tahun 1760 dan disebut sebagai periode rasionalistik, Periode kedua berlangsung antara 1760 sampai 1770, ditandai dengan semangat skeptisisme dan terpengaruh oleh Hume berangsur-angsur Kant meninggalkan rasionalisme dan merubahnya secara radikal menjadi empiristik. ${ }^{8}$ Periode ketiga dapat dikatakan sebagai 'tahap kritik' setelah karya-karyanya muncul melalui magnum opus-sya dalam The Critique of Pure Reason, Pada periode keempat berlangsung antara tahun 1790 sampai 1804, Kant lebih banyak memperhatikan unsur religi dan problema sosial melalui karyanya Religion within The Limits of Pure Reason (1794).

Introdusir Kant dimulai dari penyelidikan atas batas-batas kemampuan

\footnotetext{
${ }^{6}$ Lewis White Beck (ed), Kant On History (New York: MacMillan Publishing Company, 1989), xxvii

7 Lihat Joko Siswanto, Sistem-Sistem Metafisika Barat dari Aristoteles dampai Daridda (Yogyakarta: Pustaka Pelajar cet. 1, 1998, 58. Namun periodesasi pemikira Kant ada jugayg membaginya menjadi dua yaitu masa pra kritis dan pasca kritis, lihat Juhaya S. Praja, Aliran-aliran filsafat dan etika (Jakarta: Prenada Media, 2003), 115

${ }^{8}$ Yusuf Karam, Tarikh al-Falsafah al-Hadithah (Kairo: Dar al-Ma'arif, 1966), 211.
} 
rasio sebagai sumber pengetahuan manusia. Oleh karena itu, kritisisme sangat berbeda dengan corak Rasial modern sehelumnya yang lebih mempercayai kemampuan rasio secara mutlak. Kritisisme gagasan Immanuel Kant ini lebih condong pada teori pengetahuan, etika dan estetika. ${ }^{9}$ Munculnya pertanyaanpertanyaan: Apa yang dapat saya ketahui? Apa yang harus saya lakukan? Apa yang boleh saya harapkan? Dari ketiga pertanyaan mendasar di atas dapat disimpulkan bahwa:

1. Anggapan berpusat pada subjek dan bukan pada objek belaka.

2. Penegasan atas keterbatasan rasio manusia untuk mengetahui realitas atau hakikat sesuatu, rasio hanya mampu menjangkau gejala atau fenomenanya saja.

3. Pengenalan manusia atas sesuatu merupakan perpaduan antara unsur $a$ priori yang berasal dari rasio dan unsur a posteriori yang berasal dari pengalaman berupa maters.

\section{Kritisisme: Artikulasi Filosofis Kant}

Kant bermaksud untuk memugar sifat objektivitas dunia ilmu pengelahuan dengan menyepadankan unsur rasionalisme dan unsur empirisme. Karena unsur rasionalisme dianggap tidak memperhatikan pengalaman sedangkan unsur empirisme lebih mementingkan pengalaman dan aspek dinamisasi namun tidak memiliki konsep penggambaran pengalaman. ${ }^{10}$

Usaha Kant adalah menyimpulkan dan mengatasi dua aliran tersebut, satu sisi ia pertahankan semisal objektivitas, universalitas dan keniscayaan pengertian.

\footnotetext{
${ }^{9}$ Juhaya S. Praja, Aliran-aliran, 114.

${ }^{10}$ Joko Siswanto, Sistem-sistem, 60.
} 
Sedangkan di pihak lain ia terima pengertian titik tolak dari fenomena yang tidak melebihi batasan-batasannya. Pengetahuan dicapai melalui suatu perpaduan konsep dengan pengalaman. ${ }^{11}$ Kant menyebutnya sebagai transendental, yang berarti tidak dapat diamati sebagai suatu proses tetapi selalu harus diandaikan sebagai sebuah akibat.

Kritisisme yang dimunculkan oleh Kant dapat dianggap sebagai suatu upaya mendamaikan rasionalisme dengan empirisme. ${ }^{12}$ Rasionalisme mementingkan unsur a priori dalam pengenalan hingga terlepas dari segala pengalaman,, sebagaimana ide bawaan Descartes, Sedangkan empirisme menekankan pada unsur a posteriori yang berasai dari pengalaman sebagaimana yang dibawa oleh David Hume. ${ }^{13}$ Menurut Kant, baik rasionalisme maupun empirisme keduanya berat sebelah. Ia coba jelaskan bahwa pengalaman manusia merupakan paduan antara dua sintesa di atas. Akan tetapi berbcda dengan para pemikir abad pertengahan yang lain, dasar Kant lebih pada epistimologis daripada metafisika. Dengan bertujuan pada kritik validitas ilmu pengetahuan, menguji operasionalitasnya dan menentukan batas-batas ilmu pengetahuan itu sendiri.

Gagasan Kant ini dimunculkan oleh bentrokan epistemologis yang timbul dari rasionalisme Jerman seperti yang dikembangkan oleh Wolff dengan empirisme yang dikembangkan di Inggris dan bcrmuara pada pemikiran Hume. Kant mencoba mengatasi 'bentrokan' ini dengan menunjukkan unsur-unsur mana dalam pikiran manusia yang berasal dari pengalaman dan yang terdapat dalam

\footnotetext{
${ }^{11}$ www.bartleby.com/65ka/Kant-Imm.htm

12 Ibid, 61

${ }^{13}$ www.bartleby.com./65ka/Kant_Imm.htm
} 
akalnya. $^{14}$ Salah satu hal yang diperdebatkan adalah soal objektivitas pengetahuan, apakah pengetahuan benar-benar objektif dari akal manusia atau berasal dari pengalaman.

Kant menyebut filsafatnya sebagai transendental dengan rumusan; ilmu pengetahuan yang meneliti dengan metode dan sistem kaedah sendiri dengan muara penemuan pada cara berpikir untuk menggarap objek-objek dunia eksternal. ${ }^{15}$ Dengan prinsip a priori sebagai hal fundamental dalam penyelidikan epistemologi. Metode yang digunakan berupa metode kritis transendental dengan menyelidiki dan menjelaskan bagaimana realitas dipahami melalui medium geometri dan fisika matematis. ${ }^{16}$ Pemahaman yang dimaksud bukan dalam pengertian empiris sebagai kekuatan psikologis pcmikiran, namun sebagai pengertian transendental murni sebagai bangunan intelektualitas. Pembedaan yang dilakukan Kant atas a priori dan a posteriori diikuti pula pada pembedaan putusan; ada putusan analitis dan putusan sintetis. Untuk mewujudkan sebuah putusan diperlukan dua unsur. Unsur yang dapat ditangkap indera melalui a posteriori bersifat materiil. Sedangkan yang kedua adalah unsur formil yang bersifat a priori. ${ }^{17}$

Hingga pada akhirnya Kant membedakan tiga tingkat pengenalan; indera, akal dan budi, Pada indera munculnya kesan dan serapan indera yang nampak sebagai fenomena. Sedangkan dalam akal (verstand) dan budi (vernunft), Kant membedakan bahwa akal sebagai pengatur data inderawi yang selanjutnya

\footnotetext{
${ }^{14}$ Yusuf Karam, al-Tarikh..,213.

${ }^{15}$ Othman Amin, Naqd al-Aql al-Khalis li-Kant (Kairo: Mahragan Qiraah li al-Gami, 1995), 39.

${ }^{16}$ www.Encyclopedia_of_Phylosophy.com/Immanuel_Kant/Metaphysics/Article.htm

${ }^{17}$ Yusuf Karam, al-Tarikh., 217
} 
menjadi sebuah kategori. Dengan demikian rasio dalam mengadakan sebuah argumentasi, muncul gabungan antara data inderawi dan putusan-putusan yang pada akhirnya ditunjukkan pada tiga ide; jiwa, dunia dan Allah.

Atas dasar epistemologis yang dikembangkan Kant maka kedudukan konsep metafisik jiwa, dunia dan Allah ini menjadi sebuah konsep ide-ide transendental. Ide-ide transendetal ini adalah ide murni yang berfungsi regulatif. ${ }^{18}$ Sekalipun demikian momikirkan Ide-ide ini bukan suatu fantasi kesewenangan karena ini merupakan kewajiban untuk berpikir dan berpikir.

Pengaruh Filosofi Kant bagi Masa depan islam Indonesia

Di samping sebagai seorang filosof 'kritik', Kant juga termasuk seorang kampiun dalam bidang poiitik dan etika, Dalam sebuah seminar memperingati 200 tahun wafatnya filosof Immamael Kant di Jakarta, Matthias Lutz Bachmann seorang profesor dari Universitas Frankfurt Am Main. Jerman, mengungkapkan bahwa sosok filosof Immanuel Kant merupakan salah satu tokoh pencerahan pada abad ke-18. Dia sangat berkontribusi pada pergerakan politik. Dengan gagasan filosofisnya, yakni bentuk republik, fedcrasi ncgara-negara merdeka, dan kcramahtamahan universal (cosmopolitan right), tujuan potitik Kant adalah membuat kedamaian abadi antara individu dan antar Negara. ${ }^{19}$ Dan hal ini sesuai dengan tatanan negara republik Indonesia yang berdasarkan Pancasila. Pancasila oleh para founding fathers dimaksudkan untuk dapat menjadi tonggak pemersatu keanekaragaman yang ada di Nusantara. Pancasila dalam sila-silanya yang lima

\footnotetext{
${ }^{18}$ Ibid, 220

${ }^{19}$ Kompas, 22 Desember 2004.
} 
juga berkesuaian dengan nilai-nilai universal Islam. ${ }^{20}$ Maka dapat pula dikatakan kalau filosof Kant sebagai komplementer persatuan dan kesatuan bangsa.

Kant juga dikenal dengan gagasannya dalam demokrasi dan penjaminan hak asasi manusia. ${ }^{21}$ Dalam peringatan itu juga dibahas berbagai problematika yang relevan dengan situasi Indonesia saat Ini. Di antaranya menyangkut sejauh mana bangsa yang kuat dipengaruhi kultur dan nilai-nilai Islam dapat berdialog dengan gagasan Kant mengenai demokrasi, federalisme hak asasi manusia, kebebasan individu, serta pemisahan tegas antara moral dan hukum atau politik.

Kant berangkat dengan memperkenalkan secara filosofis martabat manusia (human dignity) atau hak sebagai manusia yang menjadi dasar dari hak asasi lainnya. Hak sebagai manusia berarti kebebasan individu dan kesetaraan. Dalam konteks ke-indonesiaan, Franz Magnis-Suseno berpandangan, Indonesia mempunyai akar budaya politik tersendiri. Dia mencontohkan ide yang terkandung dalam budaya jawa sebagai salah satu warna kuat pola kekuasaan di tanah Air. ${ }^{22}$ Sebagaimana yang telah diberikan contoh Kant dalam hal etika. ${ }^{23}$ Adalah suatu nilai etika yang berdasarkan pada kobenaran, dengan demikian perilaku moral akan senantiasa terjaga dan pada akhimya tujuan yang diinginkan

\footnotetext{
${ }^{20}$ Dalam sila ke-2 dan 5 Pancasila serta dalam pembukaan UUD 1945 terdapat dictum yang sesuai The Declaration of Human Right dan mengandung nilai universalitas Piagam Madiah tentang persamaan hak setiap individu, lihat Mohammad Sayyid al-Attar, Tayarat al-Fikr al-Muasir wa Nadzariyat al-Islam (Kairo: Dar al-Aqabah, 1993), 165.

${ }^{21}$ Dalam kajian ini banyak buku-buku dan tulisan yang mengangkat fenomena gagasan Kant dalam bidang politik ini. Seperti yang diedit oleh Hans Reiss dalam Kant:Political Writing, (Cambridge: Cambridge University Press, 1991).

${ }^{22}$ Kompas. Ibid

${ }^{23}$ Lihat kembali kajian disertasi Amin Abdullah yang telah diterbitkan pemeritah Turki, The idea of Universality of Ethical Norms in Ghazali and Kant (Ankara: Turkiye Diyanet Vakfi, 1992). Periksa juga dalam www.plato.stanford.eduentries/kant-moral.htm
} 
akan tercapai. ${ }^{24}$ Dengan demikian filosofi Kant membawa kita pada suatu arus perubahan besar yang mana atau tidak membawa nilai yang positif terutama dalam konstelasi pemikiran baik politik, sosial, budaya pendidikan dan yang lainnya. Namun tentunya ini semua akan kembali berpaling pada kita sebagai umat Islam dan bangsa Indonesia, mampu dan maukah kita untuk dapat mengejawantahkan nilai-nilai idealis yang ialah digagas dalam dataran praksis kehidupan ini. Jika kemampuan dan kemauan kita nonsens, maka ide-ide diatas hanya terasa muspro, tiada pengaruh apapun.

\section{Penutup}

Sebagai seorang filosof Kant mencoba untuk memberi suatu pewarnaan baru dalam kancah filsafat. Pemikiran yang dikembangkan menjadikannya sebagai filosof besar di zamannya. Dan tentu ini tidak lepas dari unsur-unsur pcrsebadanan ide yang ia kemukakan. Mcenjadikan filsafat kritis sebagai acuan utama dengan tidak mengenyampingkan peran unsur-unsur fenomena yang lain.

Tidak berlebihan kiranya bila Kant di juluki sebagai seorang 'raksasa' pemikir di zamannya. Dapat disejajarkan dengan Plato dan Aristoteles sebagai seorang filosof paling penting dalam kebudayaan Barat. Karyanya sangai orisinil dan jangkauannya sangat luas. Dengan demikian pengaruh Kant tidak terkirakan. Pcncetrasi intelektualitas dan kehebatannya terlihat nyata dalam bcrbagai karyanya. Dan tentu saja daya tank filsafatnya adalah monumental dan membingungkan perasaan umum yang manual keyakinan, aspirasi dalam posisi dan struktur total. Seperti juga filsafat. struktur hidup manusia dapat diatur dangan

\footnotetext{
${ }^{24}$ Franz Magniz-Suseno, 13 Tokoh Etika dari Zaman Klasik sampai Zaman Modern (Yogyakarta: Kanisius, 1997), 144.
} 
baik dan rapi. 


\section{Daftar Pustaka}

Abdullah, M. Amin. The Idea of Universality of Ethical Norms in Ghazali and Kant, Ankara: Turkiye Diyanet Vakfi, 1992.

Amin, Othman. Naqd al-Aql al-Khalis Lil-Kant, Kairo; Mahragan Qiraah li-al Gami, 1995.

Al-Atlar, Mohammad Sayyid. Tayarat al-Fikr al-Muasir wa Nadzariyal al-Islam. Kairo: Dar al-Aqabah, 1993.

Beck, Lewis White (ed.) Kant On History, New York: MacMillan Publishing Company, 1989.

Bertens, K. Ringkasan Sejarah Filsafat. Yogyakarta: Kanisius, 1983.

Collinson, Diane. Lima Puluh Filosof Dunia Yang Menggerakkan (terj.) Ma'mur Ilzamuddin dkk. Jakarta: RajaGraimdo Pcrsada, 2001.

Hamlyn, D.W. The Penguin History of Westem Philosophy London: The Penguin Group, 1987,

Kant, Immanuel. Political Writing, (ed.) Hans Reiss. Cambridge: Cambrigde University Press, 1991.

"The Critique of Pure Reason”, dalam The Westem Philosopy (ed.) Cambrigde: Cambrigde University, 1995.

Karam, Yusuf. Tarikh al-Falsafah al-Hadithah, Kairo: Dar al-Maarif, 1966.

Praja, Juhaya S. Aliran-Aliran Filsafat dan Etika, Jakarta: Prenada Media, 2003.

Siswanto, Joko. Sistem-Sistem Metafisika Barat dari Aristoteles sampai Derrida, Yogyakarta: Pustaka Pelajar, cet. I, 1998.

Suseno, Franz Magnis. 13 Tokoh Etika dart Zaman Klasik sampai Zaman Modern. Yogyakarta: Kanisius, 1997.

Trueblood, David. FUsafat Agama (terj.) HM. Rasyidi. Jakarta: Bulan Bintang, cet. IX, 1994.

www.bartleby.com. $/ 65 \mathrm{ka} / \mathrm{Kantdnun} . \mathrm{him}$

www.Encyclopedia-of-Philosophy.com/Immanuel-Kant/Metaphysies/Article.htm

www.plato.stanford.educatries/kant-moral.htm 